$\mathrm{K}$

STUDIA Z PRAWA WYZNANIOWEGO

Tom $22-2019$

DOI: https://doi.org/10.31743/spw.5475

\title{
DOPUSZCZALNOŚĆ POTWIERDZENIA CZYNNOŚCI PRAWNYCH DOKONANYCH W BRAKU \\ LUB Z PRZEKROCZENIEM UMOCOWANIA DO DZIAŁANIA ZA WYZNANIOWĄ OSOBĘ PRAWNĄ W ŚWIETLE NOWELIZACJI ART. 39 KODEKSU CYWILNEGO
}

Streszczenie

Z dniem 1 marca 2019 r. zmieniono art. 39 kodeksu cywilnego, wprowadzając jednoznacznie sankcję bezskuteczności zawieszonej umowy zawartej za osobę prawną $\mathrm{w}$ braku lub z przekroczeniem umocowania do chwili potwierdzenia lub upływu terminu wyznaczonego do tegoż. W przypadku wyznaniowych osób prawnych dopuszczalność i skuteczność potwierdzenia takiej wadliwej czynności prawnej w wielu przypadkach może budzić poważne wątpliwości. Niejednokrotnie prawo własne nie przewiduje w sposób jasny organu właściwego w sprawach potwierdzania wadliwych oświadczeń woli. Kontrowersje co do skuteczności potwierdzenia powstają także w sytuacji, gdy normy ustrojowe wyznaniowych osób prawnych przewidują wyłącznie poprzedzające zawarcie umowy akty współdziałania podmiotów uczestniczących w wytworzeniu ich woli wewnętrznej. W niektórych przypadkach nie będzie możliwe uzupełnienie brakujących aktów współdziałania z uwagi na ukształtowanie norm kompetencyjnych. Dodatkowo w przypadku zastrzeżenia w prawie własnym wspólnoty religijnej sankcji nieważności dochodzi do rozbieżności pomiędzy systemami prawnymi - prawa państwowego i prawa wewnętrznego.

Słowa kluczowe: prawo cywilne; wyznaniowa osoba prawna; wytworzenie woli wewnętrznej; bezskuteczność zawieszona; potwierdzenie; ograniczenia reprezentacji; granice umocowania

\section{$* * * * *$}

* Dr, Zakład Prawa Kościelnego i Wyznaniowego, Wydział Prawa i Administracji, Uniwersytet Jagielloński, ul. Gołębia 9, 31-007 Kraków, e-mail: strzalamarek@gmail.com. ORCID: 0000-0003-1341-3464. 


\section{WPROWADZENIE}

$\mathrm{Z}$ dniem 1 marca 2019 r. zmianie uległ przepis art. 39 kodeksu cywilnego ${ }^{1}$. Ustawa nowelizująca ${ }^{2}$ (w swoim art. 1) jednoznacznie przesądziła o dopuszczalności potwierdzenia czynności prawnych dokonanych w bra$\mathrm{ku}$ lub z przekroczeniem umocowania organu osoby prawnej. Poprzednio w literaturze ${ }^{3}$ i orzecznictwie ${ }^{4}$ prezentowane były rozbieżne poglądy co do możliwości potwierdzenia takich wadliwych czynności prawnych w zależności od przyjmowanych konsekwencji naruszenia zasad działania osób

1 Ustawa z dnia 23 kwietnia 1964 r. Kodeks cywilny, tekst jedn. Dz. U. z 2019 r., poz. 1145 .

2 Ustawa z dnia 9 listopada 2018 r. o zmianie niektórych ustaw w celu wprowadzenia uproszczeń dla przedsiębiorców w prawie podatkowym i gospodarczym, Dz. U. z 2018 r., poz. 2244.

Buczkowski 1972, 119; Dmowski 2011, 163 i 166; Frąckowiak 2012, 1147-1155; Gniewek 2011, 91-95; Grzybowski 1985, 375; Księżak 2009, 588; Machnikowski 2011, 156; Majda 2009, 660-662, 667 i 670-671; Piasecki 2003, 229; Rudnicki 2011, 314-316 i 471; Szer 1967, 208; Winiarz 1989, 55; Wypiórkiewicz 2005, 98.

4 Zob. m.in. orzeczenie Sądu Najwyższego z dnia 17 sierpnia 1988 r., III CZP 62/88, OSNC z 1989 r. Nr 4, poz. 65, LEX nr 9317; wyrok Sądu Najwyższego z dnia 26 sierpnia 1999 r., III CKN 682/98, Wokanda z 1999 r. Nr 11, poz. 5, Monitor Prawniczy z 2000 r. Nr 1, poz. 6, Biuletyn SN z 1999 r. Nr 11, poz. 11, LEX nr 452804; wyrok Sądu Najwyższego z dnia 15 lutego 2002 r., III CKN 494/99, LEX nr 54459; wyrok Sądu Najwyższego z dnia 14 stycznia 2004 r., I CK 54/03, OSNC z 2005 r. Nr 2, poz. 35, Wokanda z 2004 r. Nr 9, poz. 2, Biuletyn SN z 2004 r. Nr 6, poz. 7, Monitor Prawnicz z 2004 r. Nr 20, poz. 947, LEX nr 108160; uchwała Sądu Najwyższego z dnia 23 lipca 2004 r., III CZP 35/04, OSNC z 2005 r. Nr 7-8, poz. 125, Prokuratura i Prawo (wkł.) z 2005 r. Nr 2, poz. 35, Biuletyn SN z 2004 r. Nr 7, poz. 7, Wokanda z 2004 r. Nr 10, poz. 10, LEX nr 112849; wyrok Sądu Najwyższego z dnia 8 października 2004 r., V CK 76/04, OSNC z 2005 r. Nr 10, poz. 175, OSP z 2006 r. Nr 7-8, poz. 88, Biuletyn SN z 2005 r. Nr 4, poz. 13, Monitor Prawniczy z 2006 r. $\mathrm{Nr} 4$, poz. 202, LEX nr 148146; wyrok Sądu Najwyższego z dnia 3 marca 2005 r., II CK 409/04, OSNC z 2006 r. Nr 2, poz. 33, OSP z 2006 r. Nr 10, poz. 111, Biuletyn SN z 2005 r. Nr 10, poz. 11, LEX nr 156990; uchwała Sądu Najwyższego z dnia 14 września 2007 r., II CZP 31/07, OSNC z 2008 r. Nr 2, poz. 14, Prokuratura i Prawo (wkł.) z 2009 r. Nr 2, poz. 42 , OSP z 2008 r. Nr 5, poz. 56, Biuletyn SN z 2007 r. Nr 9, poz. 7, Prawo Bankowe z 2008 r. Nr 1, poz. 11, Monitor Prawniczy z 2008 r. Nr 2, poz. 89, LEX nr 298667; wyrok Sądu Najwyższego z dnia 9 listopada 2007 r., V CSK 278/06, LEX nr 467478; wyrok Sądu Najwyższego z dnia 5 lutego 2009 r., I CSK 297/08, OSNC-ZD z 2009 r. Nr 3, poz. 86, LEX nr 494004; wyrok Sądu Najwyższego z dnia 2 marca 2012 r., I UK 300/11, LEX nr 1170219. 
prawnych (nieistnienia oświadczenia woli, nieważności bezwzględnej lub bezskuteczności zawieszonej), dopuszczalności stosowania poprzez analogię regulacji dotyczących przekroczenia zakresu pełnomocnictwa (art. 103 k.c.) lub zgody osoby trzeciej (art. 63 k.c.).

Wobec jednoznacznego wprowadzenia dopuszczalności potwierdzenia czynności prawnej dokonanej w braku lub z przekroczeniem umocowania organu osoby prawnej, uzasadniona jest analiza nowej regulacji w kontekście wyznaniowych osób prawnych. Celem niniejszego artykułu jest przedstawienie dopuszczalności potwierdzenia wadliwych czynności prawnych dokonanych za wyznaniową osobę prawną, ewentualnych przesłanek skuteczności oświadczeń o potwierdzeniu oraz zasygnalizowanie możliwych wątpliwości i trudności z nimi związanych.

\section{POTWIERDZENIE JAKO OŚWIADCZENIE WOLI ZASTĘPOWANEJ OSOBY PRAWNEJ}

Potwierdzenie czynności prawnej, jako że zmierza do wywołania zamierzonych skutków w zakresie prawa cywilnego, samo w sobie stanowi czynność prawną, której immanentnym elementem jest oświadczenie woli. Innymi słowy potwierdzenie oświadczenia woli osoby prawnej złożonego w braku lub z przekroczeniem umocowania samo też jest oświadczeniem woli tej osoby prawnej. Wykładnię tę potwierdza sama treść znowelizowanego art. $39 \S 1$ k.c., który stanowi expressis verbis o potwierdzeniu „przez osobę prawną, w której imieniu umowa została zawarta”. Wynika to także z zasad działania osób prawnych opisanych w art. 38 k.c., w świetle którego działaniami osoby prawnej są wyłącznie działania jej organów w sposób przewidziany w ustawie i opartym na niej statucie, co oznacza, że oświadczenie woli można przypisać osobie prawnej tylko wtedy, gdy zostało złożone przez organ uprawniony do składania oświadczeń woli jako takich.

W rezultacie w przypadku działania w braku umocowania (co będzie zachodzić w sytuacji, w której oświadczenie woli złożyła osoba fizyczna nie będąca w ogóle uprawniona do składania oświadczeń woli za wyznaniową osobę prawną, czyli nie będącą piastunem organu reprezentacji), potwierdzenie wymagać będzie przeprowadzenia standardowej dla danej 
czynności prawnej procedury wytworzenia woli wewnętrznej, podjęcia decyzji o potwierdzeniu oraz złożenia przez organ reprezentacji oświadczenia o potwierdzeniu. Konieczność złożenia oświadczenia o potwierdzeniu dotyczy także sytuacji, w której przekroczenie umocowania było wynikiem uchybienia przesłankom wytworzenia woli wewnętrznej, w szczególności w postaci obowiązku współdziałania innych organów wyznaniowej osoby prawnej lub podmiotów spoza jej struktury organizacyjnej (np. w postaci obowiązku uzyskania zgody). Należy zauważyć, że umocowanie organu reprezentacji obejmuje wyłącznie objawienie wytworzonej uprzednio w prawem przepisanej procedurze woli wewnętrznej osoby prawnej i przekracza on swoje umocowanie w każdym przypadku, gdy nie doszło do jej wytworzenia. Nadto, w sytuacji przekroczenia granic umocowania do składania oświadczeń woli za osobę prawną, do skutecznego potwierdzenia nie jest wystarczające samo uzyskanie odpowiednich aktów współdziałania (w szczególności w postaci odpowiednich zgód innych organów) ${ }^{5}$, lecz konieczne jest dodatkowo złożenie kolejnego oświadczenia woli o potwierdzeniu przez organ reprezentacji wyznaniowej osoby prawnej. Rozwiązanie to należy ocenić pozytywnie, gdyż wyznaniowa osoba prawna może nie być zainteresowana $\mathrm{w}$ potwierdzeniu zaistniałej w przeszłości wadliwej czynności prawnej na skutek zmiany okoliczności i nie powinna być związana w tym zakresie decyzją podmiotu współdziałającego ${ }^{6}$.

5 Przykładowo w przypadku postanowienia zastrzegającego zgodę na sprzedaż nieruchomości do kompetencji organu innego niż organ reprezentacji, ten ostatni przed złożeniem oświadczenia o potwierdzeniu winien uzyskać zgodę organu właściwego do udzielenia zgody. W przypadku Kościoła Katolickiego, jeśli przyjąć możliwość następczego udzielania zgód, rad, upoważnień i zezwoleń (zob. niżej), co do zasady potwierdzenie wymagać będzie ich uzyskania.

6 Konsekwencją konieczności złożenia przez osobę prawną oświadczenia woli o potwierdzeniu jest to, że musi być ono być złożone przez piastuna organu reprezentacji. W rezultacie, w przypadku wadliwości pierwotnego oświadczenia woli na skutek przekroczenia granic umocowania, może się zdarzyć, że oświadczenie o potwierdzeniu, będzie składała ta sama osoba fizyczna, która działała za osobę prawną w ramach pierwotnej, wadliwej czynności prawnej. W szczególności sytuacja taka może zachodzić w przypadku jednoosobowych organów reprezentacji wyznaniowych osób prawnych. Rozwiązanie takie może budzić wątpliwości, zwłaszcza z uwagi na potencjalne ryzyko potwierdzania (ponownie z pominięciem reguł wytworzenia woli wewnętrznej) przez piastunów organów reprezentacji oświadczeń woli dokonanych uprzednio przez nich samych z przekroczeniem umocowania. W takich 
BRAK MOŻLIWOŚCI POTWIERDZENIA

Fakt, że potwierdzenie wadliwej czynności prawnej jest również czynnością prawną ma doniosłe znaczenie i powoduje, że aktualizują się wszystkie wymogi skutecznego składania przez organ reprezentacji oświadczenia woli. W szczególności organ reprezentacji będzie uprawniony do złożenia oświadczenia woli o potwierdzeniu wadliwej czynności prawnej wyłącznie w przypadku podjęcia decyzji o takim potwierdzeniu zgodnie z normami kompetencyjnymi regulującymi ustrój danej osoby prawnej. Należy z całą mocą podkreślić w tym miejscu, że art. 39 § 1 k.c. w brzmieniu wprowadzonym przedmiotową nowelą nie modyfikuje zasad działania osób prawnych i nie stanowi przyznania uprawnienia organowi reprezentacji do samodzielnego decydowania i potwierdzania czynności prawnych dokonanych w braku lub z przekroczeniem umocowania, jeśli w świetle przepisów ustrojowych nie jest on również organem decyzyjnym właściwym w sprawie potwierdzania wadliwych czynności prawnych.

Przedmiotowa nowelizacja zdaje się zakładać możliwość potwierdzenia każdej czynności prawnej (w tym każdej jednostronnej czynności prawnej, pod warunkiem zgody na działanie bez umocowania), gdyż lege non distinguente przewiduje potwierdzenie lub wyznaczenie terminu na jego dokonanie w każdym przypadku. Istnieją jednak przypadki, gdy pomimo dopuszczenia przez art. 39 k.c. potwierdzenia wadliwej czynności prawnej będzie ono niemożliwe lub co najmniej wątpliwe w przypadku niektórych wyznaniowych osób prawnych. Może to być w szczególności wynikiem niewłaściwego ukształtowania struktury kompetencyjnej organów wyznaniowej osoby prawnej polegającej na braku organu uprawnionego do podjęcia decyzji o potwierdzeniu lub specyficznie uregulowanej procedury wytworzenia woli wewnętrznej, uniemożliwiającej podjęcie decyzji co do

przypadkach sporna może być skuteczność oświadczenia o potwierdzeniu. W efekcie można, mimo wszystko raczej teoretycznie, rozważać nawet sytuację swoistego ,potwierdzenia łańcuszkowego", w którym dochodziłoby do potwierdzenia oświadczenia woli o potwierdzeniu pierwotnie wadliwej czynności prawnej. Pomimo powyższego, wykładnia językowa nowego brzmienia art. 39 § 1 k.c. i zasady teoretyczne działania osób prawnych skłaniają do wniosku, że oświadczenie o potwierdzeniu jest oświadczeniem składanym przez organ reprezentacji. Nie sposób jednak w tym momencie przewidzieć, czy ta interpretacja przyjmie się w doktrynie i judykaturze. 
dokonania samej czynności prawnej (niezależnie od możliwości podjęcia decyzji co do samego potwierdzenia) ${ }^{7}$.

\section{BRAK ORGANU KOMPETENTNEGO W ZAKRESIE DECYZJI \\ O POTWIERDZENIU WADLIWEJ CZYNNOŚCI PRAWNEJ}

W świetle treści znowelizowanego art. 39 § 1 k.c. wymogiem ważności oświadczenia woli złożonego przez organ reprezentacji w braku lub z przekroczeniem umocowania do działania za osobę prawną jest jego potwierdzenie. Przepis ten nie rozstrzyga o tym, jaki organ jest kompetentny do podjęcia decyzji o potwierdzeniu wadliwej czynności prawnej. Należy zatem w tym zakresie stosować zasady ogólne dotyczące ustroju i organizacji osób prawnych. W zakresie organizacji (w tym norm kompetencyjnych) kodeks cywilny odsyła do właściwych przepisów i w za-

7 Poza wskazanymi okolicznościami, w których powstają wątpliwości co do dopuszczalności i skuteczności potwierdzenia czynności prawnej wyznaniowej osoby prawnej dokonanej w braku lub z przekroczeniem umocowania można wskazać jeszcze inne. Potwierdzenie, o którym mowa w art. 39 k.c. zdaje się dotyczyć takich czynności prawnych, które zostały dokonane z naruszeniem zasad działania wyznaniowych osób prawnych wynikających z ich norm ustrojowych, w szczególności złożeniu oświadczenia woli przez organ reprezentacji pomimo naruszenia tzw. ograniczeń reprezentacji. Natomiast wydaje się on nie dotyczyć sytuacji, w której wadliwość czynności prawnej polegała na naruszeniu zakazu ustawowego, czy szerzej - zakazu prawa powszechnie obowiązującego. Powstaje zatem problem, czy jeśli wymóg uzyskania współdziałania innego podmiotu do skuteczności czynności prawnej przybiera postać takiego właśnie zakazu, można stosować potwierdzenie, o którym mowa w art. 39 k.c., czy też należy przyjąć nieważność na mocy art. $58 \S 1$ k.c. Przykładem condicio iuris, który budzi wątpliwości z punktu widzenia kwalifikowania go w kategoriach naruszenia umocowania i możliwości potwierdzenia, o których mowa w art. 39 k.c., jest obowiązek uzyskania zgód opisanych w art. 44 ust. 1 ustawy z dnia 21 kwietnia 1936 r. o stosunku Państwa do Muzułmańskiego Związku Religijnego w Rzeczypospolitej Polskiej (Dz. U. z 1936 r. Nr 30, poz. 240 z późn. zm.). Podobnie za warunki prawa mogłyby być traktowane wymogi kontroli kanonicznej (zob. niżej), jeśli przyjąć, że prawo kanoniczne (w tym przewidziane w nim warunki ważności aktów dotyczących majątku kościelnego) stało się na mocy odesłania częścią polskiego porządku prawnego z mocą równą prawu powszechnie obowiązującemu. Ten ostatni pogląd wydaje się przyjęto w orzeczeniu Sądu Najwyższego z dnia 24 marca 2004 r., IV CK 108/03, OSNC z 2005 r. $\mathrm{Nr} 4$, poz. 65, LEX nr 145184. 
kresie w tych przepisach przewidzianym także do statutu osoby prawnej (art. 35 i 38 k.c.).

Regulacje w zakresie struktury kompetencyjnej organów wyznaniowych osób prawnych mogą się istotnie różnić w zależności od konkretnego przypadku. Ponadto można domniemywać, że nie przewidują one expressis verbis kompetencji do potwierdzania wadliwych czynności prawnych w rozumieniu art. 39 k.c. (chociażby ze względu na nowość tej instytucji, choć konstrukcja bezskuteczności zawieszonej była już wcześniej prezentowana $\mathrm{w}$ orzecznictwie i literaturze ${ }^{8}$ ). $\mathrm{Z}$ tej przyczyny ustalanie organu kompetentnego w kwestii potwierdzenia najczęściej następować będzie poprzez ustalenie organu właściwego w pewnej kategorii spraw, do których zaliczać się będzie potwierdzanie wadliwych czynności prawnych. Problematyczna będzie jednak sytuacja, jeśli potwierdzenia nie będzie można przyporządkować do żadnej z kompetencji określonych poprzez wskazanie ich kategorii.

Kwalifikacja potwierdzenia z punktu widzenia katalogu kompetencji wyznaniowych osób prawnych jest problematyczna przede wszystkim z tego powodu, że nie ma ono charakteru majątkowego, albowiem oświadczenie o potwierdzeniu wadliwej czynności prawnej należy kwalifikować w kategoriach uprawnienia kształtującego ${ }^{9}$. Tymczasem statuty wielu rejestrowych wyznaniowych osób prawnych niejednokrotnie przewidują przede wszystkim kompetencje decyzyjne w zakresie majątkowym, finansowym i gospodarczym ${ }^{10}$. W przypadku przyznania wyłącz-

\footnotetext{
8 Zob. wyżej.

9 Tak na gruncie potwierdzenia czynności prawnej rzekomego pełnomocnika: Gawlik 1985, 763 .

10 Zob. np. § 39 statutu „Wspólnoty Bez Bram” Mumon-Kai Związku Buddyjskiego Zen Rinzai w Rzeczypospolitej Polskiej, opubl. w: Brożyniak, Winiarczyk-Kossakowska 2014, 332-336; § 34 statutu Kościoła Jezusa Chrystusa w Werbkowicach, opubl. w: Brożyniak, Winiarczyk-Kossakowska 2014, 518-522; § 9 i § 10 pkt 2 i 3 statutu Kościoła Miłosiernego Boga, opubl. w: Brożyniak, Winiarczyk-Kossakowska 2014, 537-538; § 23 ust. 1, $\S 25$ pkt 1, 2 i 10, § 26 ust. 2 i 7 pkt 1 oraz 10, 35 statutu Związku Buddyjskiego Khordong w Polsce, opubl. w: Brożyniak, Winiarczyk-Kossakowska 2014, 557-562; § 18 ust. 9 pkt c i d statutu Wspólnoty Chrześcijańskiej „Wrocław dla Jezusa”, opubl. w: Brożyniak, Winiarczyk-Kossakowska 2014, 619-623; § 9 pkt 5 statutu Kościoła Bożego w Polsce, opubl. w: Brożyniak, Winiarczyk-Kossakowska 2014, 635-649; § 49 pkt 3 statutu Kościoła Pentakostalnego w Rzeczypospolitej Polskiej, opubl. w: Brożyniak, Winiarczyk-Kossakowska
} 
nie kompetencji tego rodzaju, pojawia się kwestia, czy jakikolwiek organ jest władny podjąć decyzję o potwierdzeniu wadliwej czynności prawnej. Przyjmując zasadę, że organy osób prawnych dysponują wyłącznie kompetencjami przyznanymi w ustawie i ewentualnie w opartym na niej statucie, należałoby udzielić odpowiedzi negatywnej ${ }^{11}$. W szczególnych przypadkach może się okazać, że do podjęcia decyzji o potwierdzeniu czynności prawnej uprawniony będzie inny organ, niż właściwy w sprawie dokonania samej czynności prawnej ${ }^{12}$. W każdym przypadku ustalenie

2014, 643-649; § 10 ust. 1 pkt 8 i 9 oraz ust. 4, § 25, § 11 i $§ 15$ pkt 1 statutu Społeczności Chrześcijańskiej „Miejsce Odnowienia”, opubl. w: Brożyniak, Winiarczyk-Kossakowska 2014, 698-701; § 14 pkt 1, 6 i 8 statutu Centrum Chrześcijańskiego KANAAN, opubl. w: Brożyniak, Winiarczyk-Kossakowska 2014, 702-705; § 20 pkt 3 i 4 statutu Chrześcijańskiego Kościoła „Maranatha” w Wiśle, opubl. w: Brożyniak, Winiarczyk-Kossakowska 2014, 716-721; art. 13 pkt 7 i 9 statutu Związku Hatha Jogi „Brama Jogi”, opubl. w: Brożyniak, Winiarczyk-Kossakowska 2014, 841-843; § 15 statutu Kościoła Chrześcijańskiego „Słowo Wiary”, opubl. w: Brożyniak, Winiarczyk-Kossakowska 2014, 878-884. Zob. też: $§ 24$ ust. 1 statutu Radha Govind Society of Poland, opubl. w: Brożyniak, Winiarczyk-Kossakowska 2014, 451-454.

11 W odniesieniu do wyznaniowych osób prawnych o ustroju jednoorganowym i prawidłowo skonstruowanych normach kompetencyjnych oczywiste jest, że decyzja o potwierdzeniu należeć będzie do tego organu. Natomiast wątpliwość pozostaje w sytuacji, gdy normy kompetencyjne regulują uprawnienia decyzyjne jedynego organu na zasadzie katalogu enumeratywnego. W takim wypadku, w braku zamieszczenia w takim katalogu kompetencji uprawnienia do potwierdzenia oświadczeń woli złożonych w braku lub z przekroczeniem umocowania zachodzą wątpliwości co do dopuszczalności takiego potwierdzenia w myśl powołanej zasady, że organy osoby prawnej dysponują tylko kompetencjami przyznanymi im przez normy ustrojowe. Pewnym rozwiązaniem w przypadku wyznaniowych osób prawnych o strukturze jednoorganowej jest uznanie w myśl wykładni funkcjonalnej, że jedyny organ dysponuje pełnią kompetencji. Nie jest to jednak argument rozstrzygający, gdyż można mu przeciwstawić tezę, iż ograniczenie kompetencji jedynego organu było zabiegiem celowym norm ustrojowych. Ponadto argumentacja ta zawodzi w przypadku wyznaniowych osób prawnych o wieloorganowej strukturze.

12 Tak się może zdarzyć zwłaszcza na skutek wprowadzenia w statutach domniemania kompetencji konkretnego organu. Zob. np. § 24 ust. 1 in principio statutu Kościoła Chrystusowego w Polsce, opubl. w: Brożyniak, Winiarczyk-Kossakowska 2014, 217-219; § 29 statutu Buddyjskiego Związku Diamentowej Drogi linii Karma Kagyu, opubl. w: Brożyniak, Winiarczyk-Kossakowska 2014, 224-228; § 15 pkt 4 statutu Kościoła Chrześcijan Wiary Ewangelicznej w Rzeczypospolitej Polskiej, opubl. w: Brożyniak, Winiarczyk-Kossakowska 2014, 292-304; § 21 ust. 1 pkt 15 statutu Międzynarodowego Towarzystwa Świadomości Kryszny, opubl. w: Brożyniak, Winiarczyk-Kossakowska 
organu kompetentnego w przedmiocie potwierdzenia czynności prawnej dokonanej w braku lub z przekroczeniem umocowania przez organ reprezentacji wymaga szczegółowej analizy norm ustrojowych wyznaniowej osoby prawnej.

2014, 337-351; art. 18 pkt 11 statutu Centrum Biblijnego „Jezus jest Panem”, opubl. w: Brożyniak, Winiarczyk-Kossakowska 2014, 397-401; art. 19 ust. 1 pkt 4 statutu Stowarzyszenia Muzułmańskiego Ahmadiyya, opubl. w: Brożyniak, Winiarczyk-Kossakowska 2014, 427-430; § 23 ust. 5 pkt 6 statutu Związku Buddyjskiego Tradycji Karma Kamtzang w Polsce, opubl. w: Brożyniak, Winiarczyk-Kossakowska 2014, 539-544; § 25 pkt 10 statutu Związku Buddyjskiego Khordong w Polsce; § 18 pkt 12 statutu Chrześcijańskiego Kościoła Głosicieli Dobrej Nowiny, opubl. w: Brożyniak, Winiarczyk-Kossakowska 2014, 588-592; § 18 ust. 2 pkt 8 statutu Misji Buddyjskiej - Trzy Schronienia w Polsce, opubl. w: Brożyniak, Winiarczyk-Kossakowska 2014, 593-596; § 18 ust. 3 i $~ 31$ statutu Polskiego Kościoła Słowiańskiego, opubl. w: Brożyniak, Winiarczyk-Kossakowska 2014, 597-600; § 14 pkt 4 statutu Rodzimej Wiary, opubl. w: Brożyniak, Winiarczyk-Kossakowska 2014, 557-660; § 19 ust. 1 statutu Kościoła Chrześcijańskiego w Warszawie, opubl. w: Brożyniak, Winiarczyk-Kossakowska 2014, 675-679; § 24 ust. 1 statutu Chrześcijańskiego Kościoła Dobra, opubl. w: Brożyniak, Winiarczyk-Kossakowska 2014, 680-684; $\S 12$ ust. 3 pkt 15 statutu Centrum Chrześcijańskiego „Nowa Fala”, opubl. w: Brożyniak, Winiarczyk-Kossakowska 2014, 690-693; art. 18 ust. 2 statutu Kościoła Panteistycznego „Pneuma”, opubl. w: Brożyniak, Winiarczyk-Kossakowska 2014, 694-697; § 18 ust. 3 pkt k statutu Związku Buddyjskiego Dak Szang Kagyu w Polsce, opubl. w: Brożyniak, Winiarczyk-Kossakowska 2014, 712-715; § 23 pkt 13 statutu Kościoła Chrześcijańskiego Nowe Życie, opubl. w: Brożyniak, Winiarczyk-Kossakowska 2014, 783-788; § 22 pkt 14 statutu Kościoła Ewangelicznego w Rzeczypospolitej Polskiej, opubl. w: Brożyniak, Winiarczyk-Kossakowska 2014, 861-871; art. 25 statutu Gminy Wyznaniowej Starozakonnych w Rzeczypospolitej Polskiej, opubl. w: Brożyniak, Winiarczyk-Kossakowska 2014, 872-877; § 16 pkt 10 i § 24 statutu Chrześcijańskiego Kościoła Reformacyjnego, opubl. w: Brożyniak, Winiarczyk-Kossakowska 2014, 885-901; § 27 pkt 8 i 19 statutu Ligi Muzułmańskiej w Rzeczypospolitej Polskiej, opubl. w: Brożyniak, Winiarczyk-Kossakowska 2014, 902-909; § 10 ust. 7 statutu Ewangelicznego Kościoła Chrześcijańskiego, opubl. w: Brożyniak, Winiarczyk-Kossakowska 2014, 925-929; art. 14 ust. 2 statutu Polskiego Narodowego Katolickiego Kościoła w Rzeczypospolitej Polskiej, opubl. w: Brożyniak, Winiarczyk-Kossakowska 2014, 941-959. Zob. też § 14 pkt 7 statutu Polskiej Rady Ekumenicznej, opubl. w: Brożyniak, Winiarczyk-Kossakowska 2014, 1035-1040; $\S 25$ pkt 8 statutu Alians Ewangeliczny w Rzeczypospolitej Polskiej, opubl. w: Brożyniak, Winiarczyk-Kossakowska 2014, 1055-1060. 


\section{WARUNEK UPRZEDNIOŚCI WSPÓŁDZIAŁANIA PODMIOTÓW DECYZYJNYCH}

W niektórych sytuacjach, nawet przy istnieniu organu właściwego do podjęcia decyzji o potwierdzeniu wadliwej czynności prawnej, złożenie skutecznego oświadczenia woli o potwierdzeniu może nie być możliwe. Decyzja o potwierdzeniu powzięta przez kompetentny organ nie uzupełnia bowiem uchybionych przesłanek wytworzenia woli wewnętrznej odnośnie dokonania samej wadliwej czynności prawnej ${ }^{13}$. Innymi słowy, skuteczność oświadczenia o potwierdzeniu zależy od uzupełnienia uchybionych wymogów wytworzenia woli wewnętrznej (najczęściej w postaci uzyskania przez organ reprezentacji odpowiednich zgód innych organów wyznaniowej osoby prawnej). Niejednokrotnie jednak statuty rejestrowych wyznaniowych osób prawnych przewidują kolejność współdziałania przy wytwarzaniu woli wewnętrznej, stanowiąc m.in. expressis verbis o „uprzedniości”14 zgody lub przewidując $\mathrm{w}$ innych sformułowaniach poprzedzanie oświadczenia woli o dokonaniu czynności prawnej aktem współdziałania ${ }^{15}$. W ta-

13 Przykładowo, gdy przekroczenie umocowania przez organ reprezentacji było wynikiem nieuzyskania odpowiedniej zgody innego organu wyznaniowej osoby prawnej, uzyskanie takiej zgody stanowi element niezbędny do skutecznego potwierdzenia przez organ reprezentacji wadliwej czynności prawnej. Stanowisko przeciwne prowadziłoby do trudno akceptowalnych konsekwencji polegających na możliwości dokonywania przez organ reprezentacji czynności prawnych z przekroczeniem swojego umocowania, a następnie samodzielnym ich potwierdzaniu (pod warunkiem, że jest on też organem decyzyjnym w zakresie potwierdzenia), co w rezultacie przeczyłoby sensowi wprowadzania w procedurach decyzyjnych obowiązku współdziałania z innymi organami wyznaniowej osoby prawnej.

14 Zob. art. 17 pkt 6 statutu Kościoła Jezusa Chrystusa Świętych w Dniach Ostatnich, opubl. w: Brożyniak, Winiarczyk-Kossakowska 2014, 191-194; § 33 ust. 3 i 4 statutu Buddyjskiego Związku Diamentowej Drogi linii Karma Kagyu; art. 14 ust. 5 i art. 15 ust. 4 statutu Zboru Ewangelicko-Baptystycznego w Katowicach, opubl. w: Brożyniak, Winiarczyk-Kossakowska 2014, 405-407; § 39 statutu Kościoła Starokatolickiego w Rzeczypospolitej Polskiej, opubl. w: Brożyniak, Winiarczyk-Kossakowska 2014, 664-670; § 42 pkt 7 i $\$ 48$ ust. 3 statutu Ligi Muzułmańskiej w Rzeczypospolitej Polskiej. Zob. też § 57 ust. 4 i 5 , $\S 91$ ust. 1 i 2, § 95 ust. 1 i 2 statutu Kościoła Chrystusowego w Rzeczypospolitej Polskiej, opubl. w: Brożyniak, Winiarczyk-Kossakowska 2014, 272-291; art. 48 ust. 3 pkt 2 statutu „Wyznawców Słońca”, opubl. w: Brożyniak, Winiarczyk-Kossakowska 2014, 1028-1034.

15 Zob. np. § 54 statutu Szkoły Zen Kwan Um w Polsce, opubl. w: Brożyniak, Winiarczyk-Kossakowska 2014, 213-216. 
kich przypadkach nie będzie możliwe dochowanie przewidzianej normami ustrojowymi procedury wytworzenia woli wewnętrznej. Dodatkowo istnieje ryzyko rygorystycznej wykładni norm statutowych, w świetle której kompetencja organów współdecydujących występuje wyłącznie przed złożeniem oświadczenia woli składającego się na wadliwą czynność prawną w myśl zasady, że organy mają wyłącznie kompetencje wyraźnie przyznane normami ustrojowymi, a te uprawniają je wyłącznie do uprzedniego współdziałania w wytworzeniu woli wewnętrznej. Podobny problem występuje w przypadku, gdy statut przewidywać będzie zatwierdzenie decyzji organu zarządzającego na najbliższym posiedzeniu organu stanowiącego ${ }^{16}$, gdyż w razie odbycia takiego posiedzenia, organ stanowiący nie będzie już dysponować kompetencją do współdziałania w wytworzeniu woli wewnętrznej wyznaniowej osoby prawnej.

Kontrowersje dotyczące możliwości skutecznego potwierdzenia czynności prawnej dokonanej w braku lub z przekroczeniem umocowania do działania za wyznaniową osobę prawną wobec wymogów uprzedniości aktów współdziałania dotyczą również wspólnot religijnych funkcjonujących w oparciu o indywidualne źródła prawa powszechnie obowiązującego, w szczególności dotyczy to także wyznaniowych osób prawnych Kościoła Katolickiego ${ }^{17}$. Kodeks prawa kanonicznego ${ }^{18}$ w przypadku tzw. aktów nadzwyczajnej administracji przewiduje explicite wymóg wcześniejszego upoważnienia od ordynariusza (kan. $1281 \S 1$ CIC'1983) $^{19}$. Podobnie w świetle polskiego tłumaczenia CIC'1983 istnieje obowiązek uprzedniego uzyskania rady (consilium) diecezjalnej Rady ds. Ekonomicznych i Kolegium Konsultorów w przypadku aktów dotyczących zarządu

16 Zob. art. 24 statutu Adwentystów Dnia Siódmego Ruchu Reformacyjnego w Rzeczypospolitej Polskiej, opubl. w: Brożyniak, Winiarczyk-Kossakowska 2014, 420-426.

17 Wśród innych wspólnot religijnych tego rodzaju zob. np. art. 57 ust. 1 i 2 Zasadniczego Prawa Wewnętrznego Kościoła Chrześcijan Baptystów w Rzeczypospolitej Polskiej z 2005 r., opubl. w: Borecki, Janik 2012, 136-148.

18 Codex Iuris Canonici auctoritate Ioannis Pauli PP. II promulgatus, Acta Apostolicae Sedis 75(1983), s. 1-317; [tekst polski w:] Kodeks Prawa Kanonicznego. 1984. Przekład polski zatwierdzony przez Konferencję Episkopatu tekst dwujęzyczny, Edward Sztafrowski (tłumaczenie) i komisja naukowa pod red. Kazimierza Dynarskiego, Poznań: Pallottinum. Dalej: CIC'1983.

19 Por. m.in. López Alarcón 1993, 793. 
o większym znaczeniu ze względu na materialny stan diecezji (kan. 1277 zd. 1 CIC'1983). Niezbędna jest zgoda tych podmiotów na akty nadzwyczajnej administracji dotyczące majątku diecezji. Podobnie odpowiednie akty współdziałania są wymagane w przypadku alienacji (kan. 1292 $\S 1$ i 2 CIC'1983), a mogą też być wymagane na podstawie innych niż kodeks prawa kanonicznego źródeł prawa kanonicznego ${ }^{20}$. Uprzedniość takich aktów współdziałania można wyprowadzać z regulacji instytucji rady oraz zgody (kan. 127 § 1 i 2 CIC'1983).

Dopuszczalność skutecznego potwierdzenia czynności prawnej dokonanej z naruszeniem ograniczeń reprezentacji wynikających z regulacji prawa kanonicznego jest kwestią niejednoznaczną. Jeśli uznać, że w odniesieniu do danej czynności prawnej prawo kanoniczne wymaga do jej ważności uprzedniego aktu współdziałania (w szczególności rady, zgody, upoważnienia lub zezwolenia), to, przyjmując wykładnię literalną, wymogu tego nie sposób uzupełnić po złożeniu oświadczenia woli składającego się na wadliwą czynność prawną. Podjęte później akty współdziałania, jako dokonane z naruszeniem procedury wytworzenia woli wewnętrznej i wbrew prawu kanonicznemu, mogą zostać uznane przez sądy państwowe i inne organy władzy publicznej za nieskuteczne. Dodatkowym argumentem za nieskutecznością późniejszych aktów współdziałania jest brak wyraźnej regulacji prawa kanonicznego dopuszczającej taką możliwość, a kan. 1296 CIC'1983 można intepretować w ten sposób, że przemawiać on będzie przeciwko możliwości następczego udzielania rad, zgód, upoważnień i zezwoleń. Do podobnych wniosków prowadzi także wykładnia funkcjonalna - celem wspomnianych aktów współdziałania jest ochrona majątku kościelnego przed niekorzystnymi transakcjami, tymczasem nawet pomimo bezskuteczności zawieszonej czynności prawne dokonane z przekroczeniem granic umocowania mogą rodzić negatywne konse$\mathrm{kwencje}^{21}$. Z drugiej strony niektórzy przedstawiciele doktryny dopuszcza-

20 Zob. szerzej na temat ograniczeń reprezentacji wyznaniowych osób prawnych Kościoła Katolickiego: Strzała 2016, 110-137.

21 Przykładowo zawarcie umowy sprzedaży rzeczy z naruszeniem zasad dotyczących alienacji (przy przyjęciu dopuszczalności zezwolenia następczego) powoduje stan bezskuteczności zawieszonej. W konsekwencji zarządca majątku kościelnego musi liczyć się z możliwością udzielenia skutecznego (jeśli przyjąć jego dopuszczalność) zezwolenia następczego. W rezultacie będzie on ograniczony w dokonywaniu czynności prawnych 
ją możliwość sanowania braków w zakresie procedur decyzyjnych poprzez udzielenie następczo brakującego zezwolenia lub zgody ${ }^{22}$. Niezależnie od innych problemów ${ }^{23}$, istnieje poważne ryzyko skutecznego zakwestionowania aktów współdziałania dokonanych ex post.

\section{ROZBIEŻNOŚĆ PORZĄDKÓW PRAWNYCH PAŃSTWOWEGO I WEWNĘTRZNEGO WSPÓLNOT RELIGIJNYCH}

Rozpatrując znaczenie przedmiotowej nowelizacji dla wyznaniowych osób prawnych, warto wskazać na dodatkowy aspekt wprowadzenia bezskuteczności zawieszonej jako sankcji działania w braku lub z przekroczeniem umocowania. Mianowicie w przypadku, gdy prawo własne wspólnot religijnych przewiduje sankcję nieważności w przypadku uchybienia procedurom decyzyjnym w nim przewidzianym, zaś polskie prawo cywilne sankcję bezskuteczności zawieszonej, dochodzi do rozdźwięku pomiędzy oboma systemami prawnymi - państwowym oraz prawa własnego wspólnoty religijnej. Przykładem może być sankcja nieważności przewidziana wprost w kan. $1281 \S 1$ CIC'1983 (co nota bene dodatkowo przemawia przeciwko możliwości udzielenia upoważnienia ex post, gdyż nie sposób udzielać upoważnienia na akt, który w świetle prawa kanonicznego jest

potencjalnie korzystnych dla wyznaniowej osoby prawnej (np. problematyczne będzie wydzierżawienie takiej rzeczy, które przyniosłoby korzyść ekonomiczną w postaci czynszu dzierżawnego).

22 Zob. m.in. Pawluk 1990, 52 i tam wskazana literatura; Wybrańczyk 2018, 62-63. Por. jednak: Kennedy 2000, 1506, przyp. 174.

${ }_{23}$ Osobną kwestią jest m.in. kwalifikacja samego potwierdzenia wadliwej czynności prawnej z punktu widzenia instytucji prawa kanonicznego, a w szczególności, czy można by je traktować w kategoriach aktu nadzwyczajnej administracji (na gruncie niektórych aktów prawa partykularnego) lub alienacji sensu largo. W razie zakwalifikowania samego potwierdzenia do tego rodzaju aktów, aktualizują się dodatkowe wymogi związane kontrolą kanoniczną względem samego potwierdzenia. W efekcie oprócz uzupełnienia brakujących zgód, rad, zezwoleń i upoważnień wymaganych dla pierwotnie zamierzonej a bezskutecznie zawieszonej czynności prawnej, konieczne byłoby również uzyskanie tego rodzaju aktów dla samej zamierzonej czynności potwierdzenia. Analiza, czy potwierdzenie należy uznać za akt nadzwyczajnej administracji lub rodzaj alienacji sensu largo przekracza jednak możliwości niniejszego opracowania. 
nieważny i jako taki nie wywołujący skutków prawnych). Inny przykład stanowi $§ 42$ ust. 8 Regulaminu Parafialnego Kościoła Ewangelicko-Augsburskiego ${ }^{24}$, w świetle którego brak stosownej uchwały Rady Parafialnej lub brak zgody właściwej Władzy Kościelnej skutkuje nieważnością czynności prawnej. Także w tym przypadku przemawia to przeciwko dopuszczalności skutecznego potwierdzenia czynności prawnej dokonanej w braku lub z przekroczeniem umocowania.

W opisanych sytuacjach, nawet jeśli przyjąć na forum prawa państwowego możliwość potwierdzenia wadliwej czynności prawnej i jego skuteczność, to na gruncie prawa własnego wspólnoty religijnej czynność prawna nadal pozostanie nieważna. W konsekwencji będzie zachodziła rozbieżność pomiędzy oboma systemami prawnymi. W przypadku woli dopuszczenia przez wspólnotę religijną możliwości potwierdzenia wadliwej czynności prawnej, w tych przypadkach w których jej prawo własne nie przewiduje takiej możliwości i stanowi o sankcji nieważności, należałoby dokonać odpowiednich zmian prawa wewnętrznego. Innymi słowy, konsekwencją przedmiotowej nowelizacji jest konieczność zmian prawa własnego wspólnot religijnych przewidującego sankcję nieważności i niedopuszczalność potwierdzenia wadliwych czynności prawnych, by nie dochodziło do coraz większego rozdźwięku pomiędzy systemami prawnymi i wynikającego $\mathrm{z}$ tego chaosu prawnego, o ile zamierzeniem wspólnoty religijnej jest zgodność obu porządków prawnych.

\section{PODSUMOWANIE}

Z uwagi na krótki czas obowiązywania regulacji wprowadzonej przedmiotową nowelą nie wykształciła się jeszcze linia orzecznicza dotycząca stosowania potwierdzenia czynności prawnych dokonanych w braku umocowania lub z jego przekroczeniem w przypadku wyznaniowych osób prawnych. Kwestia dopuszczalności potwierdzenia takich czynności prawnych w wielu przypadkach może być dyskusyjna. W pierwszej kolejności potwierdzenie może budzić wątpliwość w przypadku tych wyznaniowych

24 Tekst jedn. z dnia 24 czerwca 2015 r. https://bik.luteranie.pl/files/Prawo/2015-06-24 RegulaminParafialnytekstjednolityBIK.pdf [dostęp: 30.08.2019]. 
osób prawnych, których struktura kompetencji nie przewiduje organu właściwego w sprawach potwierdzania wadliwych oświadczeń woli. Nadto kontrowersje wywołuje zagadnienie dopuszczalności i skuteczności potwierdzenia w tych sytuacjach, w których normy ustrojowe wyznaniowych osób prawnych przewidują wyłącznie uprzednie, względem oświadczenia woli składającego się na daną czynność prawną, akty współdziałania podmiotów uczestniczących w wytworzeniu woli wewnętrznej. Wobec niejednoznacznej skuteczności ewentualnych następczych aktów współdziałania należy postulować w przypadku wadliwych czynności prawnych przeprowadzenie procedury decyzyjnej w pełni na nowo i następnie złożenia nowego oświadczenia woli odpowiadającego pierwotnej, wadliwej czynności prawnej, zamiast dokonywania jej potwierdzenia, o ile za potwierdzeniem nie przemawiają poważne racje, uzasadniające podjęcie ryzyka jego nieskuteczności i związanych z tym konsekwencji prawnych.

\section{BIBLIOGRAFIA}

Borecki, Paweł, Czesław Janik. 2012. Prawo wewnętrzne nierzymskokatolickich związków wyznaniowych w Polsce - wybór aktów prawnych. Warszawa: Dom Wydawniczy Elipsa.

Brożyniak Ryszard, Małgorzata Winiarczyk-Kossakowska. 2014. Mniejszości wyznaniowe w Polsce. Prawo wewnętrzne (statutowe). Warszawa: Wydawnictwo Sejmowe.

Buczkowski, Stefan. 1972. W: Franciszek Błahuta, Wiktor Bryl, Stefan Buczkowski, Ryszard Czarnecki, Henryk Dąbrowski, Jerzy Ignatowicz, Ludwik Kostowski, Juliusz Krzyżanowski, Edward Kulesza, Witalis Kuryłowicz, Bronisław Łubkowski, Józef Majorowicz, Zbigniew Masłowski, Zbigniew Mika, Edward Montalbetti, Jan Pawlak, Mieczysław Piekarski, Janusz Pietrzykowski, Jan Policzkiewicz, Stanisław Rejman, Zbigniew Resich, Zbigniew Rzepka, Józef Szczerski. Kodeks Cywilny: Komentarz. T. I. Warszawa: Wydawnictwo Prawnicze.

Dmowski, Stanisław. 2011. W: Stanisław Dmowski, Stanisław Rudnicki. Komentarz do Kodeksu cywilnego. Księga pierwsza. Część ogólna. Warszawa: Wydawnictwo Prawnicze LexisNexis.

Frąckowiak, Jerzy. 2012. „Osoby prawne”. W: System Prawa Prywatnego. T. I. Prawo cywilne - część ogólna, red. Marek Safjan. Warszawa: Wydawnictwo C.H. Beck. 
Gawlik, Bogusław. 1985, W: System prawa cywilnego. Część ogólna, t. I, red. Stefan Grzybowski. Wrocław: Zakład Narodowy im. Ossolińskich.

Gniewek, Edward (red.). 2011. Kodeks cywilny. Komentarz. Warszawa: Wydawnictwo C.H. Beck.

Grzybowski, Stefan. 1985. W: System prawa cywilnego. Część ogólna, t. I, red. Stefan Grzybowski. Wrocław: Zakład Narodowy im. Ossolińskich.

Kennedy, Robert T. 2000. W: New commentary on the Code of Canon Law, red. John P. Beal, James A. Coriden, Thomas J. Green. New York - Mahwah: Paulist Press. Księżak, Paweł. 2009. W: Kodeks cywilny. Część ogólna. Komentarz, red. Małgorzata Pyziak-Szafnicka. Warszawa: Wolters Kluwer Polska.

López Alarcón, Maria. 1993. W: Code of Canon Law Annotated: Latin-English edition of the Code of Canon Law and English-language translation of the 5th Spanish-language edition of the commentary prepared under the responsibility of the Instituto Martin de Azpilcueta, red. Ernest Caparros, Michel Theriault, Jean Thorn. Montreal: Wilson \& Lafleur.

Machnikowski, Piotr. 2011. Kodeks cywilny. Komentarz, red. Edward Gniewek. Warszawa: Wydawnictwo C.H. Beck.

Majda, Rafał. 2009. W: Kodeks cywilny. Część ogólna. Komentarz, red. Małgorzata Pyziak-Szafnicka. Warszawa: Wolters Kluwer Polska.

Pawluk, Tadeusz. 1990. Prawo kanoniczne wg Kodeksu Jana Pawła II. T. IV. Doczesne dobra Kościoła. Sankcje w Kościele. Procesy. Olsztyn: Warmińskie Wydawnictwo Diecezjalne.

Piasecki, Kazimierz. 2003. Kodeks Cywilny. Księga pierwsza. Część ogólna. Kraków: Zakamycze.

Rudnicki, Stanisław. 2011. W: Stanisław Dmowski, Stanisław Rudnicki. Komentarz do Kodeksu cywilnego. Księga pierwsza. Część ogólna. Warszawa: Wydawnictwo Prawnicze LexisNexis.

Strzała, Marek. 2016, „Ograniczenia reprezentacji wyznaniowych osób prawnych Kościoła Katolickiego" Krakowski Przeglad Notarialny 2: 107-138.

Szer, Seweryn. 1967. Prawo cywilne. Część ogólna. Warszawa: Państwowe Wydawnictwo Naukowe.

Winiarz, Jan. 1989. Kodeks Cywilny z Komentarzem. T. I. Warszawa: Wydawnictwo Prawnicze.

Wybrańczyk, Daniela. 2018, „Obrót nieruchomościami kościelnymi z naruszeniem prawa" Rejent 9: 58-78.

Wypiórkiewicz, Andrzej. 2005. W: Helena Ciepła, Bronisław Czech, Stanisław Dąbrowski, Tadeusz Domińczyk, Henryk Pietrzkowski, Zbigniew Strus, Marek Sychowicz, Andrzej Wypiórkiewicz. Kodeks cywilny: praktyczny komentarz z orzecznictwem, t. I. Warszawa: Wydawnictwo Zrzeszenia Prawników Polskich. 


\section{ADMISSIBILITY OF CONFIRMING LEGAL ACTIONS PERFORMED ON BEHALF OF LEGAL PERSONS OF RELIGIOUS ORGANIZATIONS WITHOUT OR OUTSIDE THE MANDATE OF REPRESENTATION IN LIGHT OF THE AMENDMENT TO ARTICLE 39 OF THE POLISH CIVIL CODE}

\section{Summary}

Article 39 of the Polish Civil Code was amended on March 1, 2019. One of the changes brought in by the amendment is the sanction of suspended ineffectiveness of a contract concluded on behalf of a legal entity without or outside the mandate of representation, which applicable until the contract is confirmed or until a given contract confirmation date. As far as legal persons of religious organizations are concerned, the admissibility and effectiveness of confirming such defective legal actions may raise serious doubts in many cases. The internal law of a religious organization often fails to clearly indicate a body competent for confirming defective declarations of will. Controversies over the effectiveness of such confirmations also arise in cases when the institutional norms of legal persons of religious organization permit only acts of cooperation between subjects participating in developing their internal will before a contract is concluded. In some cases, it will be impossible to supply the missing acts of cooperation due to the shape of relevant competence norms. In addition, when the internal law of a religious organization includes the sanction of contract ineffectiveness, there arises a conflict between the two legal systems - state law and internal law of a religious organization.

Key words: civil law; legal person of a religious organization; development of internal will; suspended ineffectiveness; confirmation; restrictions to representation; limits of the mandate of representation 
